Full-text Available Online at www.ajol.info and www.bioline.org.br/ja

\title{
A Study of the Constraint to Formulation and Implementation of Waste Management Policies in Benin Metropolis, Nigeria
}

\author{
${ }^{* 1}$ DI. IGBINOMWANHIA; BA; IDEHO \\ ${ }^{1}$ Corresponding author: Mechanical Engineering Department, \\ Faculty of Engineering, University of Benin, Benin City, Nigeria \\ ${ }^{2}$ Department of Social Science and Philosophy, Development and International Cooperation, \\ University of Jyväskylä, Finland
}

KEYWORDS: Constraints, Solid Waste Management, Policy Frame Work, Implementation and Benin Metropolis

\begin{abstract}
In recent years, Benin metropolis has been faced with solid waste management problems. Solid wastes generated from household and commercial activities are dump indiscriminately in the metropolis. The Edo state government has made effort in policy formulation and funding in line with the national policy on the environment to resolve the solid waste problems in the metropolis but the effort has not yielded good result. Hence, we propagated that there are some salient policy problems bedeviling the waste management sector that when addressed have the capacity to resolve the waste management problems and improve on the well-being of the residents. This study was therefore aimed at analysing the existing constitutional and policy framework with a view to identifying the constraints to formulation and implementation of coherent waste management policies and recommend feasible solutions. Primary information on waste management policies were obtained from the waste management agencies and residents in the metropolis through the use of questionnaires and oral interview. Results obtained showed that there are no inadequate human and material resources for formulation and implementation of waste management policies. Considering the findings, there is urgent need for the formulation and implementation effective and efficient solid waste management policies in the metropolis. (C) JASEM
\end{abstract}

\section{http://dx.doi.org/10.4314/jasem.v18 i2.7}

Introduction: The increase in urbanization and population growth has caused a corresponding increase in solid waste generated from household and commercial activities in many towns and cities in Nigeria. In Benin metropolis about 461,412.3kg per day of solid waste is generated from residential source (Igbinomwanhia, 2010). With the near absence of proper integration of solid waste collection and disposal methods in urban planning and subsequent absence of proper policy formulation and implementation to arrest such situations, solid waste is thus disposed indiscriminately around the metropolis.

The policy that created the default federal environmental protection agency (FEPA) was repealed because it failed to integrate grassroots involvement in its formulation. It has been assumed that existing policies at the local level have been formulated and implemented mainly from urban considerations (Egwurube, 1983)
However, the formulation and implementation of incoherent policies in the waste management sector has made solid waste management to be commonly seen in Nigeria as simply "pick up the waste and go dump it in the dumpsite" whether it is approved dumpsite or illegal dumpsite.

The solid waste management practice at the approved dumpsite is simple. The waste disposal trucks collect waste from household and businesses premises and transport them to the dumpsite. At the dumpsites the trucks drive in through the access roads and dump their waste. Other vehicles that deliver waste to the site simply dump their waste indiscriminately by the road sides after closing hour. The workers at the dumpsites use shovel to manually push the waste from the access road and try to spread them as much as their strength can go. Thereafter, open air incineration without pollution control is carried out on the waste for volume reduction. This is not sustainable as it does not bring financial return at the 
end point of the waste. Solid waste management has therefore become a nightmare to waste management decision makers in Benin metropolis and poor state of solid waste management in now not only an environmental problem, but also a major economic and social handicap.

Currently in Nigeria the main solid waste policies are formulated by the federal and state government and the implementation of the policies is concentrated at the local government level. Nevertheless, state governments have played a significant role in managing solid waste across the country. In Edo state the ministry of environment and public utilities (MEPU) is the regulatory body with the responsibility of managing the environment on behalf of the State. Under the direct supervision of MEPU is the Edo state waste management board (ESWMB) saddled with the responsibility of supervising collection, transport, processing, recycling or disposal, and monitoring of waste materials. These include solid, liquid, gaseous and radioactive substances. In managing the environment, the Ministry tackles all environmental problems ranging from Waste Management, Flood and Erosion Control, forest depletion and degradation and general environmental and atmospheric pollution. The agency has been observed to be ineffective in carrying out these responsibilities. Hence, we propagated that there are some salient policy problems bedeviling the waste management sector that when addressed have the capacity to resolve the waste management problems and improve on the well-being of the residents.

This study was therefore aimed at analysing the existing constitutional and policy framework with a view to identifying the constraints to formulation and implementation of coherent policies and recommend feasible solutions.

\section{METHODOLOGY}

This study was carried out in two phases - A study of the current waste management activities in Benin metropolis and study of solid waste policies and implementation in Benin metropolis. The first phase of the study involves the study of published and unpublished government agencies reports/records, private agency report, personal communication with private and government waste management agencies, literature review and a preliminary field work in the Benin metropolis. The second phase - study of solid waste management policies and implementation involved the following steps - collection of information on policy guidelines and implementation from the office of the ministry of environment and public utilities (MEPU), Edo state, selecting a representative sample of households and business units, the use of structured questionnaires to collect primary information from households and business unit in the metropolis and oral interview with some members of households, staff of private waste management firms and government agencies.

A multi-stage stratified-systematic sampling method (Drew, 1980) was applied for the sampling process and a total of 152 and 150 commercial units and household cooperated with the study. Each selected commercial unit and household was visited several times. In the first visits, contact was made and participation consent requested. Upon approval questionnaires were distributed, a second visit was made to retrieve the questionnaires and interviews were conducted. Further visits were made to retrieve the questionnaires and oral interview was carried out where necessary.

\section{RESULTS AND DISCUSSION}

The ministry of environment and public utilities (MEPU) of Edo state is the regulatory body with the responsibility of managing the environment on behalf of the state. Under the direct supervision of MEPU is the Edo state waste management board (ESWMB) saddled with the responsibility to support and ensure the implementation of the policy guidelines on solid waste management (Federal Ministry of Environment, 2005).

This study revealed that the agency is deficient in its responsibilities and duties because it lacks adequate man power, equipments, and proper waste disposal outfits. In addition the residents in Benin metropolis lack adequate awareness on the policies for waste management and proper disposal methods including waste sorting at source. Table 1 revealed that about $58 \%$ and $63 \%$ of households and business operators are not aware of policies on waste management. This can be attributed to the poor educational background of the residents because the study indicated that $16.96 \%$ and $33.05 \%$ of the sampled population shown in table 2 had no formal education and primary education respectively. There is also a lacks of full participation of the local government authorities. 
Table1 Respondents awareness of waste management Policies

\begin{tabular}{ccc}
\hline $\begin{array}{c}\text { Awareness of } \\
\text { Policy }\end{array}$ & $\begin{array}{c}\text { Household } \\
\text { (\% Response) }\end{array}$ & $\begin{array}{c}\text { Business } \\
\text { Operators } \\
\text { (\% Response) }\end{array}$ \\
\hline Yes & 40.00 & 36.18 \\
No & 58.67 & 63.82 \\
\hline
\end{tabular}

Constraint to formulation an implementation of waste management policy: The constraints to formulation and implementation of waste management policies in Benin metropolis have been identified in the sections below.

Constitutional Constraint: The constitutions of the Federal Republic of Nigerian (FRN) contain the supreme law of the land. This study revealed that until the ratification of the 1999 constitution, the constitution lacked a specific provision on the environment. Sections 20 of the 1999 constitution made the following provision: "the state shall protect and improve the environment and safeguard the water, air, land, forest and wild life of Nigeria" (FRN, 1999). The broad nature of the wording of this provision make it's enforcement difficult and this is a serious defects as the provision only attempts a middle-ground between two extremes formulated by a system that is not desirous of initiating any serious environmental change, the thrust of which may disturb its economic direction and strategies (Fagbohun, 2002). However, based on the provision in the constitution several environmental policies have been formulated at the state and local government levels. This study revealed that many of such policies do not conform to modern waste management practice. For example the policies at the state level provide the dumpsite option as the end point for solid waste in Edo state (Edo state, 2010) and no proper provision for the disposal of sewage and excreta.

Interview with personnel at MEPU revealed that policies formulated at the national and state levels most times are not transmitted or relayed to the households by the Local governments where most of the waste management activities are carried out. This could in part be attributed to lack of adequate check and balances between the local governments and the state authorities, inadequate funds, inadequate man power and lack of accountability. More so, the study showed that although the policies formulated at the
Table 2: Educational Background of respondents

\begin{tabular}{lcc}
\hline Level of Education & $\begin{array}{c}\text { Household } \\
\text { (\% Response) }\end{array}$ & $\begin{array}{c}\text { Business } \\
\text { Operators } \\
\text { (\% Response) }\end{array}$ \\
\hline No formal education & 16.95 & 0.66 \\
Primary Education & 33.05 & 13.16 \\
$\begin{array}{l}\text { Secondary/Higher } \\
\text { Education }\end{array}$ & 24.58 & 59.21 \\
Vocational education & 25.42 & 26.97 \\
\hline TOTAL & 100 & 100 \\
\hline
\end{tabular}

national level charge the local government with the responsibility of implementing the policy guideline on solid waste management, such as enlisting the service of the private sector and stake holders in solid waste management (Federal Ministry of Environment, 2005), the Edo state waste management board is empowered by the Edo state sanitation and pollution law to appoint private waste managers in collection and disposal of waste directly from households and business premises (Edo state, 2010). In addition the Edo state sanitation and pollution management law (Edo state, 2010) created two technical committees, one each at the state and local government levels and this duplicates the responsibilities of the waste management Board and the environmental department of the local government council. These have caused interference resulting in conflicts between the state government and local government agencies saddled with waste management in the metropolis.

Financial Constraint: Based on the provision in the constitution several environmental policies have been formulated at the state and local government level. The effective implementations of the various policies are constraint by poor funding. Waste management is given very low priority in the budget due to limited finances. As a result very limited funds are provided to the waste management sector by the governments, and the levels of services required for protection of public health and the environment are not attained. The user service charges collected by the disposal agents is too little to make any meaningful impact on waste management system. However, users' ability to pay for the services is also limited by their income, and their willingness to pay for the services which are irregular and ineffective is not high either. More so the end point of the solid waste does provide financial reward to waste disposal agent hence the only source of finance to the disposal agent is the user service charges 
Technical Constraint: In most developing countries, there is lack of human resources at both the state and local levels with technical expertise necessary for solid waste management planning and operation (Ogawa, 1996). Many officers in charge of waste management, particularly at the waste management Board and local government levels, have little or no technical background or training in environmental engineering or management (United Nations Commission on Sustainable Development, 1997). This study revealed that there is lack of human resources at both the state and local government levels and the private sector with technical expertise required for waste management planning and implementation. Many officers in charge of waste management, particularly at the state ministry of environment and other agencies handling the issues of waste, have little or no technical background or training in engineering or waste management. Hence the policies formulated do not meet modern practice. In fact all the problems that the waste Management system is faced with are exacerbated by the lack of trained personnel at the waste management policy implementation level. These include workers in all ranks, from the administrator to the refuse-men. There is no formal training program and communication is poor. Without adequately trained personnel for solid waste policy making and implementation, sustainable solid waste management planning and implementation is not realizable (Zavodska, 2003). This study also revealed that the private sector is the major player in waste collection and disposal and that there is ineffective and unreliable solid waste collection service. The private sector lack adequate equipment for collection of waste from source. Aged vehicle fleet was observed to be mainly in use. In addition a large proportion of the vehicle were observed to be open vans which results in waste littering on the way to the dump site and this violates the Edo state sanitation and pollution law (Edo state, 2010). No Engineered landfill and solid waste including medical waste is simply collected at source, transported to the dumpsite and open air burning without pollution control is carried out on the waste. All these are result of poor, inadequate and inefficient waste management policies.

Institutional Constraint: The study showed that the policies formulated at the state and local government levels in Nigeria charge the local government with the responsibility of collection and disposal of solid waste from public places and commercial unit (Federal Ministry of Environment, 2005). The local government environmental department therefore has the responsibility of picking up and transportation of solid waste from public place (Schwarz-Herion et al, 2008). In reality several agencies have been created at the state level that is involved at least partially in solid waste management (Ogawa, 1996). Such agencies at the state level include - Edo State waste management board (ESWMB), Operation Cleanup Edo State, Special Environmental task force and local government environmental task force (Edo state, 2010), that have the mandate to pick up and transport solid waste to the dumpsite. However, there are often no clear roles and functions of the various state and local government agencies defined in the policy that created them and there is no provision for coordinating their activities. The lack of coordination among the relevant agencies often results in duplication of efforts, wastage of resources, and unsustainability of overall waste management programmes. The lack of coherent legislation for solid waste management is partially responsible for the roles and functions of the relevant state and local government agencies not being clearly defined and the lack of coordination among them.

Cultural Constraint: Over the years material such as dead animals and body parts of dead animals, food items, cloth and small earthen sculptures are seen around road junction in Benin metropolis. This study revealed that the materials are item used for sacrifice and that the practice of dumping material for sacrifices such as animal parts or full dead bodies of animal at road junctions and by the road side is a cultural norm acceptable in the Bini Kingdom. Such norms affect formulation and implementation of waste management policies.

Conclusion: There are laws in Benin metropolis regarding solid waste management, but most of them are not followed as there is virtually no adequate enforcement.

The problem of solid waste in Benin metropolis is therefore not a significant increase in solid waste generation. The main problem is lack of coherent policies and incoherent implementation of existing policies for waste management resulting in the poor management of solid waste - handling, collection and disposal.

It is quite evident that waste management is an uncoordinated sector in Benin metropolis. This is due to the poor policy formulation and implementation. The constraint to policy formulation and implementation in the metropolis include the constitutional lapse in ensuring clear duties and responsibilities between the state and local governments agencies, lack of manpower with 
adequate technical training, poor funding and the obvious lack of accountability among the authorities involved in waste management.

Feasible recommendations have been made to aid the formulation and coherent implementation of waste management policies in Benin metropolis.

Recommendations: To achieve a sustainable and effective waste management system in Edo state particularly in Benin metropolis, the following should be put in place.

Review of Waste Management Policies: The current policy guidelines on solid waste management charge the local government with the collection and disposal of waste. The local government also has the responsibility of enlisting private waste manager and other stake holders, but the Edo state sanitation and pollution management law empowered the Edo state waste management board (ESWMB) to appoint private waste managers. Hence ESWMB and local government councils are both currently appointing waste managers in the metropolis and this makes supervision of the system difficult as the private waste manager appointed by ESWMB are responsible to the state government whereas, the local government council is charged with the responsibility of enlisting private waste manager (Federal Ministry of Environment, 2005).

Therefore there is need for the review of the Edo state sanitation and pollution management law in line with the provision of the policy guidelines on solid waste management. In addition considering the interference between the state and local government agencies it is imperative that solid waste management policies should be made with provision for rule of law to ensure compliance by the state and local government authorities.

Provision of Adequate Fund for Policy Implementation : This research showed that government funding for solid waste management is very poor, hence special attention need to be paid to financial budget for waste management by the ministry of environment and the local government council in the metropolis. This work also revealed that the ministry of environment and local government council currently collects some environmental charges and there are some difficulties associated with the collection of these charge. The agencies in the ministry of environment and local government council therefore need to create a financial plan that will incorporate special fees and charges that will be paid by households and business in the metropolis. The financial plan should be supported by coherent policies that eliminate the present difficulties associated with collection of levies and charges in the metropolis and these fees and charges should be dedicated to research and development of solid waste management system and management of solid waste in general in the metropolis.

iii. The state and local government authorities should take advantage of the clause in the constitution which enables it makes by-laws and create policies that ensures periodic audit of both the local government and state waste management agencies on their performance.

iv. The state government should ensure quarterly reviews of the activities carried out between the local government and the state agencies in-charge of waste disposal and management. This will help to eliminate the area of interference resulting in conflict between the state and local government agencies.

\section{Introduction of Integrated Waste Management}

System. Waste management is a complex part of the society and therefore requires a comprehensive approach. The government should create policies that ensure full integration of the private sector participation (PSP) as waste disposal and management cannot be done by the government alone without the involvement of the private sector. The policies should make integrated waste management mandatory. The private sector should be made to provide a clear plan which may involve waste resource recovery, reuse, recycling and conversion processes before enlistment. This will also help to create job opportunities as new ideas will be injected.

vi. The government should create policies that Integrate and encourage sorting waste at source as this is not currently practiced in Benin metropolis. Sorting waste at source will not only reduce cost of land filling but will also encourage effective recycling which is important in integrated waste management system.

\section{REFERENCES}

Egwurube J. (1983) Local Government and Environmental Management. Paper presented at the National Conference on Development and the Environment held at NISER University of Ibadan, Jan 17 \& 19

Edo State (2010): Edo state sanitation and pollution law, Edo state law No. 5 of 2010. 
Fagbohun O. (2002) Reappraising the Nigerian Constitution for Environmental Management. AAU law Journal Vol. 1. No.1, 44.

Federal Ministry of Environment (2005): policy guideline on solid waste management, Federal Republic of Nigeria.

Federal Republic of Nigeria (1999): Constitution of the Federal Republic of Nigeria.

Igbinomwanhia, D.I (2010): Characterization Residential Solid Waste In Benin Metropolis, Nigeria. International Journal of Engineering, Indian, Vol. 4, No. 4 (479-486)

Ogawa, H (1996) Sustainable Solid Waste Management in Developing Countries, the 7th ISWA International Congress and Exhibition, Parallel Session 7, "International Perspective. On line at: http://www.gdrc.org/uem/waste/swmfogawa1.htm. (Assessed 10th Nov. 2011).
Waste Management In Industrialized Countries By The Example Of Karlsruhe City, Germany, Journal of Annals of faculty of engineering Hunehoara. TOME VI (year 2008), FASCICULE 3, (ISSN 1584 - 2673)

United Nations Commission on Sustainable Development (1997): National Implementation of Agenda 21 (Information Provided by the Government of Nigeria to the United Nations Commission on Sustainable Development. Fifth Session 7-25 April 1997 New York

Zavodska, A. (2003). A study of residential solid waste composition and management in a selected developing country - Guyana, The Journal of solid waste management and technology, Department of Civil Engineering Widener University, Chester, U.S.A. Vol.29, No. 1

Schwarz-Herion, O. , Omran, A., Rapp, H.P. (2008), A Case Study On Successful Municipal Solid 